\title{
Microstructure and properties of 1050A/AZ31 bimetallic bars produced by explosive cladding and subsequent groove rolling process
}

\author{
Sebastian Mróz ${ }^{1} \cdot$ Renata Mola ${ }^{2} \cdot$ Piotr Szota $^{1} \cdot$ Andrzej Stefanik $^{1}$ \\ Received: 24 February 2020 / Revised: 14 May 2020 / Accepted: 10 June 2020 / Published online: 22 June 2020 \\ (c) The Author(s) 2020
}

\begin{abstract}
Within the framework of this study, the 1050A/AZ31 round bimetal bars were produced by the explosive cladding method and subsequent groove rolling process. LM/SEM investigation shown that by proper selection of the explosive cladding parameters (mainly initial distance between 1050A tube and AZ31 core and detonation velocity) it is possible to produce 1050A/AZ31 feedstocks without a continuous layer of Mg- $\mathrm{Al}$ intermetallic phases on the interface between joined materials. The experimental tests of the groove rolling process of 1050A/AZ31 bars were supplemented with a theoretical analysis using FEM-based numerical modelling. Based on the test results obtained, it was found that the interface of the 1050A/AZ31 bar rolling at a temperature $\left(300^{\circ} \mathrm{C}\right)$ was characterized by the generation of a thin continuous intermetallic layer without cracks. Applying a higher rolling temperature of $400{ }^{\circ} \mathrm{C}$, which is usually used in hot forming processes of $\mathrm{Mg}$ alloys, led to the production of a thicker intermetallic layer, which cracked during the rolling process as a result of deformation. Strength of the fabricated bimetal joints was high, they did not delaminate during shear tests.
\end{abstract}

Keywords 1050A/AZ31 bimetal bars $\cdot$ Explosive welding $\cdot$ Groove rolling $\cdot$ Microstructure analysis $\cdot$ Numerical modeling

\section{Introduction}

Magnesium and aluminium alloys are characterized by holding the lowest density of all structural metallic materials, and, therefore, are widely used in automotive, aircraft and aerospace industries. To expand the application of these materials in the transportation sector, in recent years, new types of light alloys and composites based on magnesium and aluminium are being extensively developed $[1,2]$. A promising solution in the area of lightweight structural materials is the fabrication of $\mathrm{Al} / \mathrm{Mg}$ bimetals combining the advantages of both metals: lower density of the magnesium and the better corrosion resistance of the aluminium.

Fabricating one-body material with the fully integrated and defect-free interface between these two light metals is a

Sebastian Mróz

mroz@wip.pcz.pl

1 Czestochowa University of Technology, 69 Dąbrowskiego Street, 42-201 Częstochowa, Poland

2 Kielce University of Technology, Al. Tysiąclecia Państwa Polskiego 7, 25-314 Kielce, Poland big challenge. The $\mathrm{Al} / \mathrm{Mg}$ bimetallic materials can be produced using various methods: diffusion bonding $[3,4]$, hot rolling [5, 6], extrusion $[7,8]$, welding $[9,10]$, casting [11, 12] or explosive cladding $[13,14]$.

The major problem related to the production of $\mathrm{Mg} / \mathrm{Al}$ bimetals is the occurrence of hard and brittle $\mathrm{Mg}-\mathrm{Al}$ intermetallic phases in the bonding zone. This affects the properties of the joints (strongly decreasing the mechanical properties). The thickness and structure of these zones depend on the fabrication method. In some techniques, i.e. diffusion bonding, hot rolling and extrusion, when the temperature of the process is lower than the eutectic temperature of the $\mathrm{Mg}-\mathrm{Al}$ system $\left(437{ }^{\circ} \mathrm{C}\right)$ [15], a continuous bonding zone composed of two layers of $\mathrm{Mg}-\mathrm{Al}$ intermetallic phases: an $\mathrm{Al}_{3} \mathrm{Mg}_{2}$ layer on the $\mathrm{Al}$ alloy side and an $\mathrm{Mg}_{17} \mathrm{Al}_{12}$ layer on the $\mathrm{Mg}$ alloy side [16], forms as a result of reactive diffusion between materials. In this case, the thickness of the bonding zone formed as a result of solid-state diffusion depends on the temperature and time of the process. In work [16] it was shown that bonding zone in an $\mathrm{Al} / \mathrm{AZ} 31$ specimen fabricated by diffusion bonding at $430{ }^{\circ} \mathrm{C}$ for $20 \mathrm{~min}$ was $50 \mu \mathrm{m}$ in thickness. Xiao and Wang [17] investigated the growth behaviour of intermetallic compounds during 
reactive diffusion between $\mathrm{Al}$ alloy grade 1060 $\mathrm{A}$ and $\mathrm{Mg}$. Their results show that the thickness of the bonding zone in $\mathrm{Mg}-\mathrm{Al}$ couple annealed at $400{ }^{\circ} \mathrm{C}$ for 5,20 , and $50 \mathrm{~h}$ was about 20, 150 and $220 \mu \mathrm{m}$, respectively. In work [6], the effect of the annealing on the microstructural evolution at the bond-interface $\mathrm{Al} / \mathrm{Mg}$ was investigated. The Authors used a two-pass hot rolling process to fabricate $\mathrm{Al} / \mathrm{Mg}$ laminated composites. The first pass was performed at temperature $350{ }^{\circ} \mathrm{C}$, holding time before rolling was $15 \mathrm{~min}$. No new phases formed at the bond interface after the first hot rolling pass. When the $\mathrm{Al} / \mathrm{Mg}$ specimens were annealed before the second pass at or above $300{ }^{\circ} \mathrm{C}$, a continuous layer of $\mathrm{Mg}-\mathrm{Al}$ intermetallic phases formed at the bond interface. Herein, the growth rate of the intermetallic layer increased with increasing annealing temperature, while the incubation time decreased with increasing temperature. As the $\mathrm{Mg}-\mathrm{Al}$ intermetallic layer is brittle, during the second rolling pass it was broken into fragments. The bonding zone in an $\mathrm{Al} /$ $\mathrm{Mg}$ bimetal fabricated at a temperature higher than eutectic temperature is much thicker and has a more complex structure. For example, in a 1050A/AZ31 joint fabricated by friction stir welding, the bonding zone has an irregular shape and is locally very thick (up to $4 \mathrm{~mm}$ ) [9]. The presence of the eutectic composed of $\mathrm{Mg}_{17} \mathrm{Al}_{12}$ intermetallic phase and a solid solution of $\mathrm{Al}$ in $\mathrm{Mg}$ in the structure of the bonding zone indicates that during the joining process, partial melting of the welded material occurs. In 6060/AZ31 bimetal fabricated by compound casting [18] by pouring the AZ31 magnesium alloy at $660{ }^{\circ} \mathrm{C}$ onto a solid 6060 aluminium alloy insert preheated to $300{ }^{\circ} \mathrm{C}$, the bonding zone has $400 \mu \mathrm{m}$ thickness. Apart from the $\mathrm{Mg}-\mathrm{Al}$ intermetallic phases, a eutectic $\left(\mathrm{Mg}_{17} \mathrm{Al}_{12}\right.$ and a solid solution of $\mathrm{Al}$ in $\mathrm{Mg}$ ) was observed in the microstructure of the bonding zone close to the $\mathrm{Mg}$ alloy. The same microstructure of the bonding zone was obtained in [19], where $\mathrm{Al} / \mathrm{Mg}$ bimetal was produced by pouring $\mathrm{Al}$ melt at $700{ }^{\circ} \mathrm{C}$ onto $\mathrm{Mg}$ bar preheated to $300{ }^{\circ} \mathrm{C}$. In this case, the bonding zone has a thickness about $500 \mu \mathrm{m}$. The very thick bonding zone composed of brittle $\mathrm{Mg}-\mathrm{Al}$ intermetallic phases may cause serious problems with further processing the $\mathrm{Al} / \mathrm{Mg}$ bimetals to form elements with the desired shape.

Explosive welding is a method widely employed to produce bimetal parts. In this process, the strong metallurgical bond is achieved as a result of a high-speed collision of the materials to be joined by controlled explosive detonation close to the surface of the materials. The main advantages of this method, which is classified as a solid-state joining process, are low costs of equipment, simplicity and short time of the process. In recent years, much research has been conducted in utilizing this method to join metallic materials that are either similar or dissimilar [20, 21]. As shown above, this method is successfully used to produce $\mathrm{Al} / \mathrm{Mg}$ bimetals plates [22, 23], bars [24] and elements of complex shapes
$[25,26]$. Experimental results reveal that the process parameters of the explosive welding affect the microstructure of the bonding zone directly after welding. In work [13], it was observed that the profile of the interface transforms from smooth to wavy, depending on the kinematic parameters of the collision. Literature data show that by properly selecting the process parameters, it is possible to avoid the formation of $\mathrm{Mg}-\mathrm{Al}$ intermetallic phases at the bond interface [22, 23] directly after welding. In other works, it has been found that after explosive welding, the intermetallic phases formed swirls locally and randomly distributed at the interface [13] or segmented structure [14]. To produce the elements of the desired shape, the further processing of $\mathrm{Al} / \mathrm{Mg}$ material by metal forming is applied. As Mg-based alloys are characterized by poor formability at ambient temperature, the $\mathrm{Al} / \mathrm{Mg}$ bimetals fabricated by explosive welding are processed at elevated temperatures that leads to formation of a continuous $\mathrm{Mg}-\mathrm{Al}$ intermetallic phase zone at the bond interface, the thickness of which gradually increases with increasing heating temperature and prolongation of the holding time $[22,27]$. Therefore, the heat treatment process should be controlled carefully to reduce the formation of $\mathrm{Mg}-\mathrm{Al}$ intermetallic phases and, consequently, evoke an improvement in the properties of the joint. The aim of the study was to investigate the influence of the rolling process temperature on microstructure, quality and strength of the joining area in 1050A/AZ31 round bars.

\section{Experimental details}

Explosive welding of 1050A/AZ31 bimetallic feedstocks was carried out in cooperation with the company ZTW EXPLOMET sp.j. Gałka, Szulc (Poland). Eight sets of samples were prepared for testing, each consisting of aluminium tubes (grade 1050A) and magnesium alloy round bars (grade AZ31), respectively. The chemical compositions and the mechanical properties of the materials are presented in Table 1.

The outer diameter of 1050A tubes was $24 \mathrm{~mm}$ and the tube wall thickness was $1.5 \mathrm{~mm}$. The initial distance between the AZ31 core and the inner tube diameter was $0.9 \mathrm{~mm}$. The casing of the prepared explosive welding system was made of a $50 \mathrm{~mm}$-inner diameter paper tube of $5 \mathrm{~mm}$ wall thickness. The aluminium alloy tube was shielded by a polypropylene layer of approx. $0.5 \mathrm{~mm}$ thickness. The thickness of the explosive material was approx. $12 \mathrm{~mm}$.

A diagram of the cylindrical system used for explosive bonding of an AZ31 bar to an aluminum tube is shown in Fig. 1.

An explosive called "saletrol" featuring $1620 \mathrm{~m} / \mathrm{s}$ detonation velocity was used for explosive welding. This is composed of a mixture of ammonium nitrate and diesel oil. 
Table 1 Chemical composition and mechanical properties of the joined materials

\begin{tabular}{|c|c|c|c|c|c|c|c|c|c|}
\hline \multirow{2}{*}{$\begin{array}{l}\text { Material } \\
\text { AZ31 }\end{array}$} & \multicolumn{9}{|c|}{ Chemical composition ( $\%$ mass.) } \\
\hline & $\mathrm{Mn}$ & $\mathrm{Mg}$ & $\mathrm{Cu}$ & $\mathrm{Zn}$ & $\mathrm{Ca}$ & $\mathrm{Al}$ & $\mathrm{Si}$ & $\mathrm{Fe}$ & $\mathrm{Ni}$ \\
\hline & 0.24 & base & - & 0.72 & - & 2.8 & 0.01 & 0.003 & 0.001 \\
\hline \multirow[t]{2}{*}{$1050 \mathrm{~A}$} & $\mathrm{Si}$ & $\mathrm{Fe}$ & $\mathrm{Cu}$ & $\mathrm{Mn}$ & $\mathrm{Mg}$ & $\mathrm{Zn}$ & $\mathrm{Ti}$ & $\mathrm{Al}$ & $\mathrm{Pb}$ \\
\hline & 0.06 & 0.18 & 0.002 & 0.003 & 0.002 & 0.008 & 0.020 & 99.74 & - \\
\hline \multirow[t]{2}{*}{ Material } & & & \multicolumn{7}{|c|}{ Mechanical properties } \\
\hline & & & YS (MPa) & & & UTS (MPa) & & & $\begin{array}{l}\text { Elon- } \\
\text { gation } \\
(\%)\end{array}$ \\
\hline AZ31 & & & 231 & & & 299 & & & 18 \\
\hline $1050 \mathrm{~A}$ & & & 30 & & & 80 & & & 40 \\
\hline
\end{tabular}

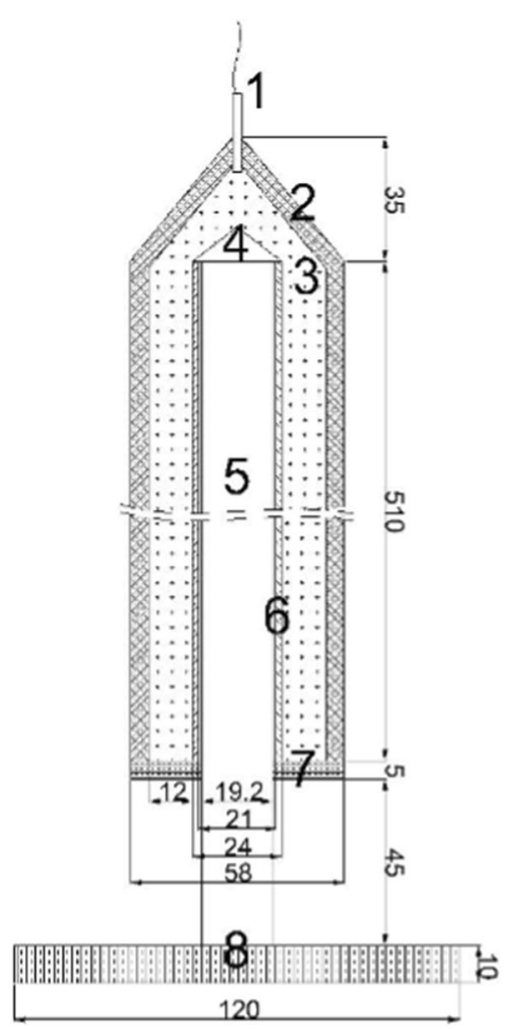

Fig. 1 A diagram of the system for explosive bonding of a 1050A tube with an AZ31 bar: 1, fuse; 2, paper tube; 3, explosive material; 4, centering plug; 5, AZ31 alloy bar; 6, aluminium tube; 7, bottom centering disc; 8 , system base

This is composed of a mixture of ammonium nitrate and diesel oil. The detonation velocity was determined using the Explomet Fo-Multimode fiber optic detonation velocity meter. After denotation, straight bimetallic bars of $500 \mathrm{~mm}$ length and with a durable and continuous bond over the entire length were obtained, with no curving and necking observed (Fig. 2a). The continuity of the joint in each 1050A/AZ31 bar after explosive welding was measured using the ultrasonic method with a shaped head adapted to round bars. The bimetal bars of $500 \mathrm{~mm}$ length, obtained in result of the explosive cladding, were characterized with slight differences of cladding layer thicknesses on the peripheries and lengths of the bars. The average thickness of the cladding layers was $1.66 \mathrm{~mm} \pm 0.1 \mathrm{~mm}$. Whereas the $\mathrm{Al}$ layer contribution within cross-section was $28 \%$. The diameter of 1050A/AZ31 following the explosive welding was $22.5 \mathrm{~mm}$ (Fig. 2b), [24, 25].

The rolling process of explosively welded bimetal 1050A/AZ31 feedstock was performed in the two-high rolling mill, with $150 \mathrm{~mm}$ working rolls diameter and $170 \mathrm{~mm}$ diameter of barrel type rolls. Each roll had individual drive provided by an asynchronous, alternating current motor, $7.5 \mathrm{~kW}$ rated power, through the reducing gear having 1:22.4 gear ratio and drive shaft. The motor was controlled by means of ACS-601 type inverter, by ABB Industry. The rolls with machined grooves, which when assembled, created the horizontal oval-circlehorizontal oval working pass (Fig. 3), were used for rolling the 1050A/AZ31 bimetal bars. Following the rolling process, round bars of $17 \mathrm{~mm}$ diameter were obtained. The velocity of the rolling process was $0.2 \mathrm{~m} / \mathrm{s}$. It has been determined on the grounds of earlier works [28] of the authors, that metal forming of analyzed 1050A/AZ31 bars can be also performed in the decreased temperature (down to $300{ }^{\circ} \mathrm{C}$ ) as compared to $\mathrm{Mg}$ alloys metal forming temperature, which ranges at $350-450{ }^{\circ} \mathrm{C}[29,30]$. It has been shown in works $[28,31]$, that application of external $\mathrm{Al}$ layer results in the cumulation of tensile stress, influencing the possibility of cracks appearing, occurring within the cladding layer and not within the $\mathrm{Mg}$ alloy core. Because the aluminum (1050A) is more plastic as compared to $\mathrm{Mg}$ alloys, this creates the possibility of widening range of temperature-deformation parameters (higher deformation velocity and lower temperature), at 
Fig. 2 Shape of $\mathrm{Mg} / \mathrm{Al}$ bimetallic bars after explosive welding: a general view, $\mathbf{b}$ cross-section of the bar (a)

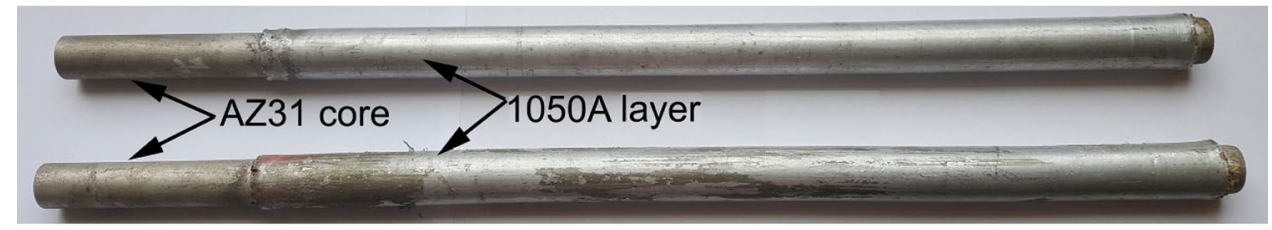

(b)

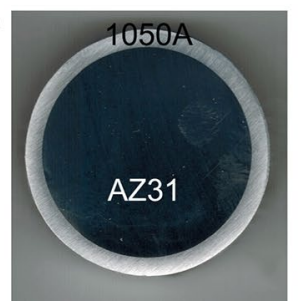

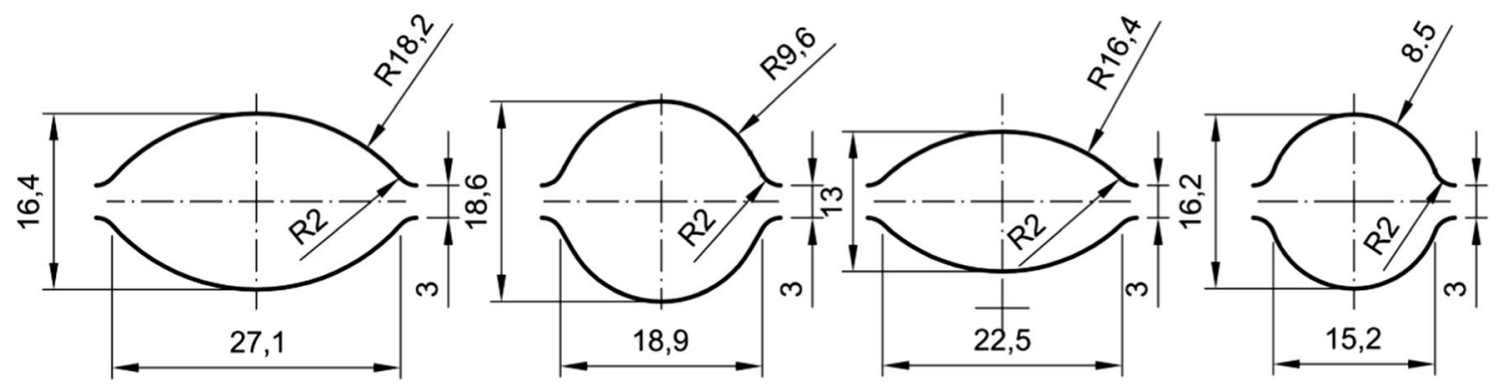

Fig. 3 The shape and dimensions of the designed stretching passes

which materials of these types can be deformed. Therefore, the rolling process was conducted at two temperatures, $400{ }^{\circ} \mathrm{C}$ and lowered down to $300{ }^{\circ} \mathrm{C}$. The templates for further research were sampled following each pass.

The 1050A/AZ31 bimetal bars were cut parallel and perpendicular to the detonation and rolling direction and prepared for microscopic observations following standard metallographic procedures. The final polishing was performed using $0.05 \mu \mathrm{m}$ colloidal silica suspension. Specimen preparation for the microscopic analysis did not involve etching. The microstructure of the bonding zone of the 1050A/AZ31 bimetal was determined by means of a Nikon ECLIPSE MA200 optical microscope and a JEOL JSM-5400 scanning electron microscope. Its chemical composition was established through X-ray energy dispersive spectrometry (EDS) using an Oxford Instruments ISIS 300 analysis system. The microhardness of the joints was measured with a MATSUZAWA MMT Vickers hardness tester under a load of $100 \mathrm{~g}$. Tests of the joint strength were done by means of Zwick Z100 machine. The experimental research was supplemented with computer simulations and analysis of strain distribution within the joint, executed with FEM-based Forge $2011^{\circledR}$ computer software.

\section{Results and discussion}

Figures 4 and 5 show the transverse and longitudinal sections of the 1050A/AZ31 bimetal bar produced using explosive welding method. At low magnification image (Fig. 4a), at the transverse section, it can be seen that the 1050A/AZ31 interface was not smooth with recesses and cambers occurring at irregular intervals. Figure 4b, c show the interface observed at higher magnification. Here, it is evident that no new phases exist at the interface between alloys (Fig. 4b), but, locally, areas with irregular shape are visible (Fig. 4c), arrows in Fig. 4a. This indicates that during the explosive welding process new phases formed between the joined alloys.

The examination of the morphology of the interface at the longitudinal section at low magnification (Fig. 5a) shows it holds a highly regular wavy form. In addition, small areas of new phases with irregular shape (Fig. 5b, c) and arrows in Fig. 5a were observed locally at the interface.

Figure 6 shows the SEM image of the 1050A/AZ31 interface of the explosive welded bar, respectively; the corresponding EDS line scan results showing the 
Fig. 4 Microstructure of the bonding zone of a 1050A/ AZ31 bimetallic bar fabricated by explosive welding: a low magnification LM image, $\mathbf{b}, \mathbf{c}$ high magnification LM images. Transverse section (a)

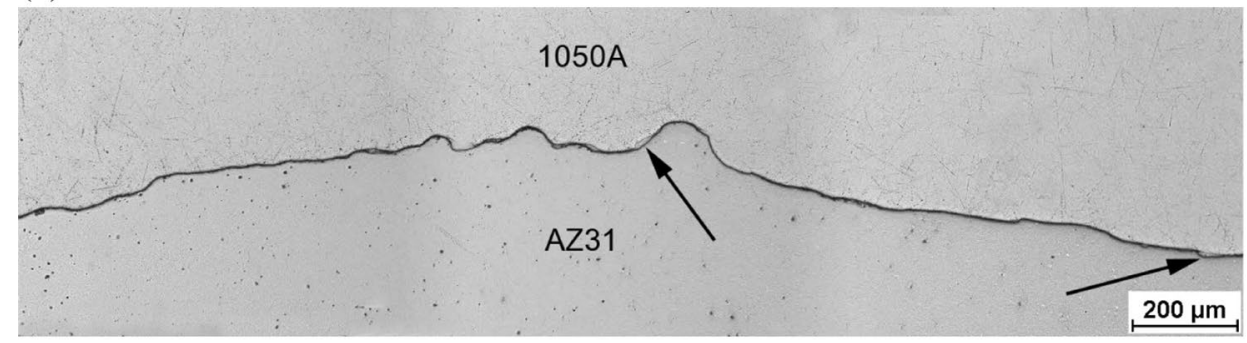

(b)

(c)

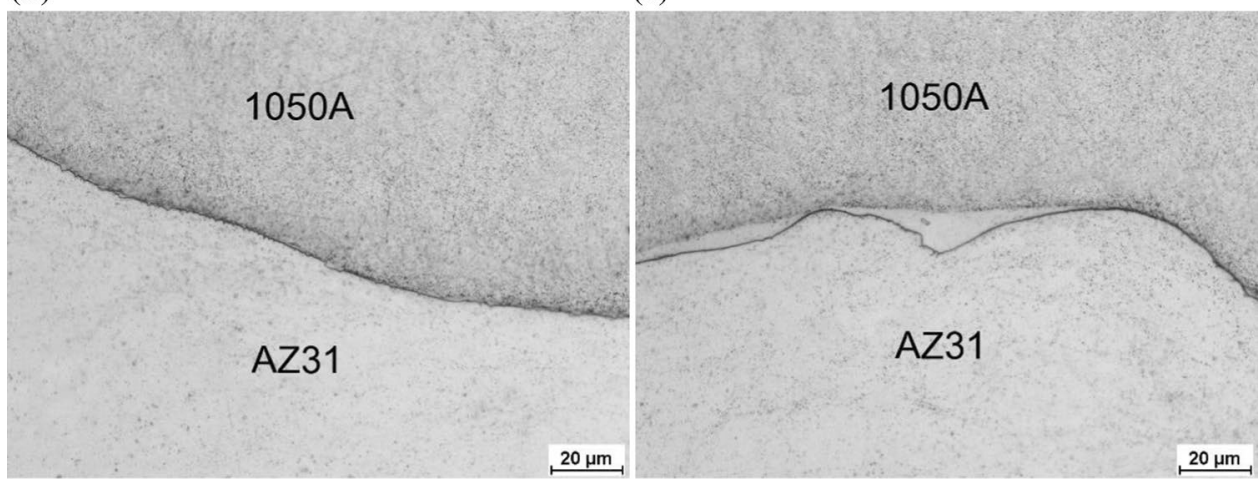

(a)

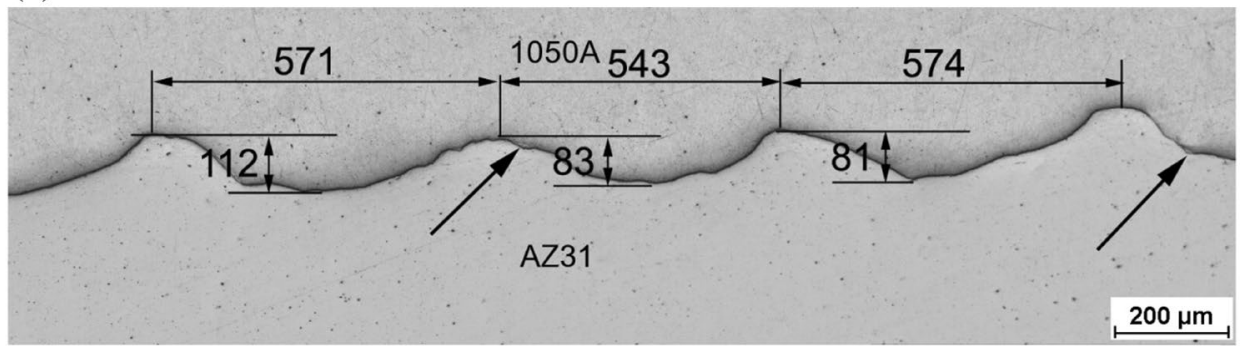

(b)

(c)

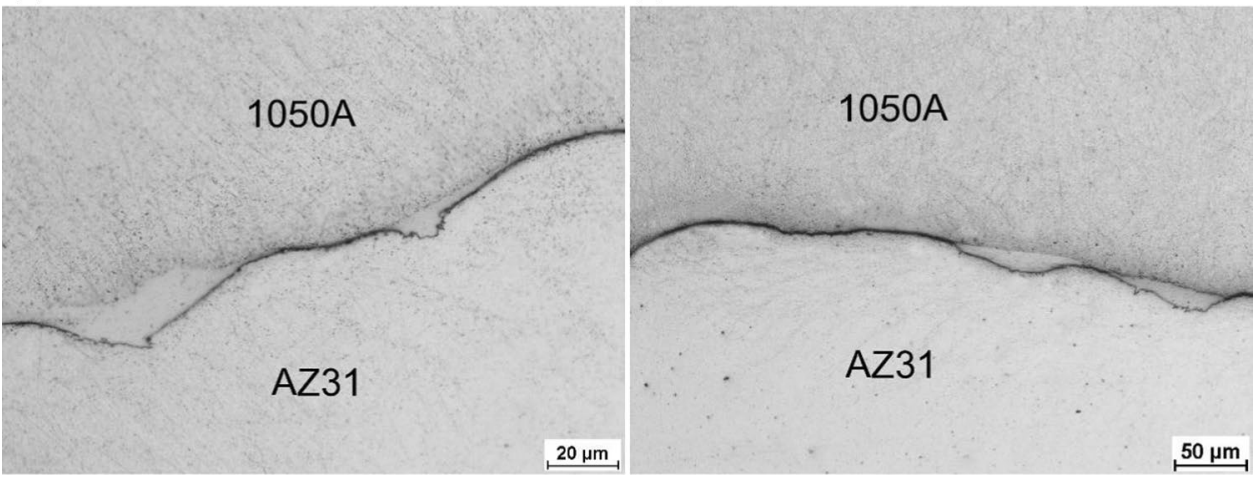

concentration profiles of the $\mathrm{Mg}$ and $\mathrm{Al}$ are also included. The sharp transition between concentration $\mathrm{Mg}$ and $\mathrm{Al}$ at the interface (Fig. 6a) indicates that no new phases formed between the alloys during explosive welding. SEM investigations (Fig. 6b) confirm the previous LM observation that locally there are irregularly shaped areas of non-homogeneous microstructure. The distribution of elements along the marked line indicates that in this area there are darker regions rich in $\mathrm{Mg}$ and lighter regions rich in Al. The quantitative EDS analysis in the darker region (point 1 in Fig. $6 \mathrm{~b} ; 55.4$ at.\% $\mathrm{Mg}$ and 44.6 at.\% $\mathrm{Al}$ ) indicates the presence of the $\mathrm{Mg}-\mathrm{Al}$ intermetallic phase. The chemical composition of the lighter region (point 2 in Fig. 6b); 13.66 at.\% Mg and 86.34 at.\% Al corresponds 
Fig. 6 SEM microstructure of the interface in 1050A/ AZ31 bimetallic bar fabricated by explosive welding with a distribution of elements $(\mathrm{Mg}$, $\mathrm{Al})$ along the marked line: $\mathbf{a}$ without new phases, $\mathbf{b}$ with area of $\mathrm{Mg}-\mathrm{Al}$ phases (a)

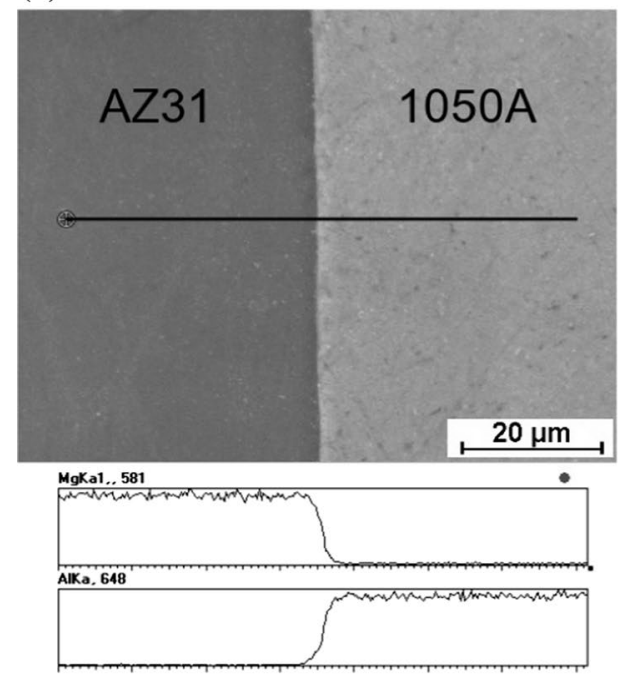

(b)

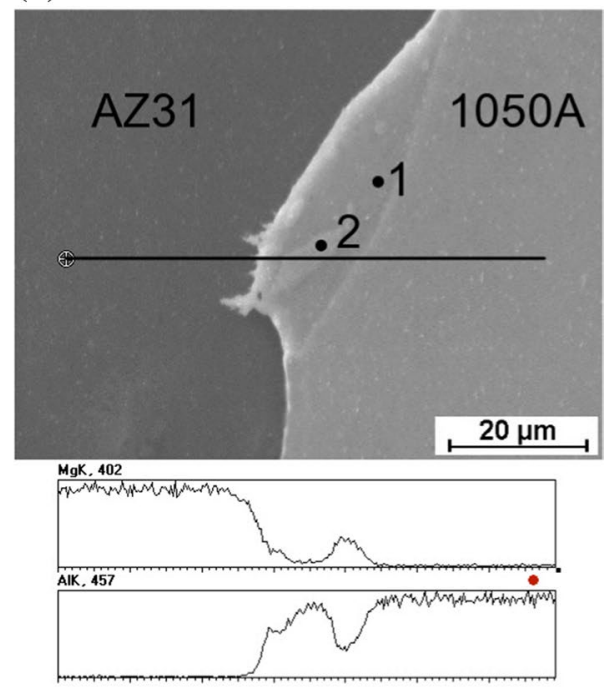

to a solid solution of $\mathrm{Mg}$ in Al. Microstructure analysis of the explosive welded multi-layer materials carried out by other authors [13, 32, 33] also indicates a similar phenomenon-that irregularly shaped areas with non-homogenous structure composed of new phases were locally and randomly distributed at the bond interface. During explosive welding, one metal collides with another at high speed and the temperature increases rapidly near the interface which leads to local melting of the joined alloys. During cooling the melt composed of both components solidified and, therefore, the area of new phases were visible locally at the interface.

The 1050A/AZ31 bimetallic bars fabricated by explosive cladding were subsequently worked by groove rolling at 300 and $400{ }^{\circ} \mathrm{C}$. At the first investigation stage, changes in the shape and dimensions of bars after individual passes were examined (Fig. 7).

It comes from the data shown in Fig. 7, that in any case (despite different rolling temperatures have been used) delamination of components at the joint border did not occur. Confirmation of the high quality of bonding area were comparable values of shear strength obtained for individual rolling variants and cross-sectional view of samples without lack of delamination after shear tests (Fig. 14). In work [34] it has been shown that even partial delamination of components during groove rolling of bimetallic bars results in a significant (up to $30 \%$ ) decrease in joint strength compared to samples with a continuous bonding zone.

Reduction of rolling temperature, according to earlier results of the authors' works [28, 31], reduced "flowing" the cladding layer of the magnesium core, which resulted in lower differences in the height and length of the bars, as compared to the bars rolled at $400{ }^{\circ} \mathrm{C}$.

The microstructure of the interface at the transverse and longitudinal section of the 1050A/AZ31 bar after rolling at $300{ }^{\circ} \mathrm{C}$ is shown in Figs. 8 and 9, respectively.

At the transverse section it can be observed that after the rolling process, the cambers and cavings occurring at the bond interface were significantly flattened (Fig. 8a). In LM images, at higher magnification, (Fig. 8b, c) next
Fig. 7 The shape and dimensions of templates after rolling in the classic system of passes: a rolling at $300{ }^{\circ} \mathrm{C}, \mathbf{b}$ rolling at $400{ }^{\circ} \mathrm{C}$

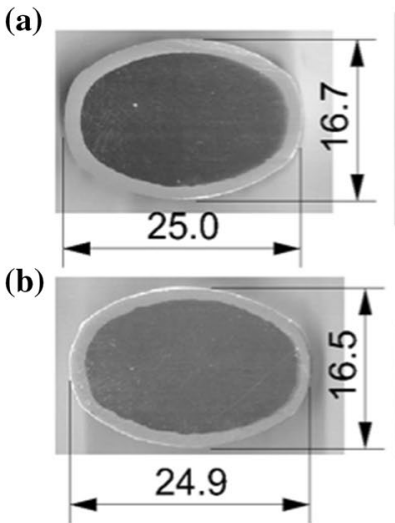

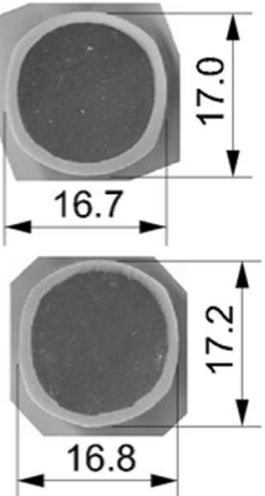


Fig. 8 Microstructure of the bonding zone of a 1050A/AZ31 bimetallic bar after rolling at $300{ }^{\circ} \mathrm{C}$ : a low magnification LM image, b, $\mathbf{c}$ high magnification LM images. Transverse section

Fig. 9 Microstructure of the bonding zone of a 1050A/AZ31 bimetallic bar after rolling at $300{ }^{\circ} \mathrm{C}$ : a low magnification LM image, $\mathbf{b}, \mathbf{c}$ high magnification LM images. Longitudinal section (a)

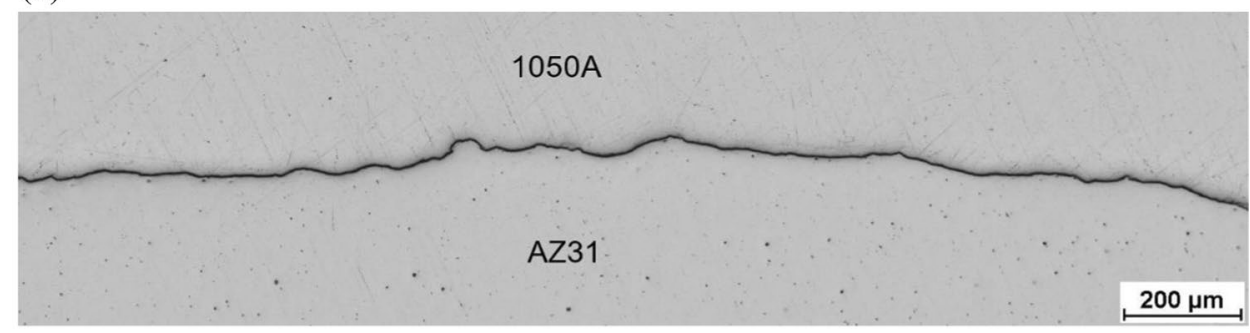

(b)

(c)
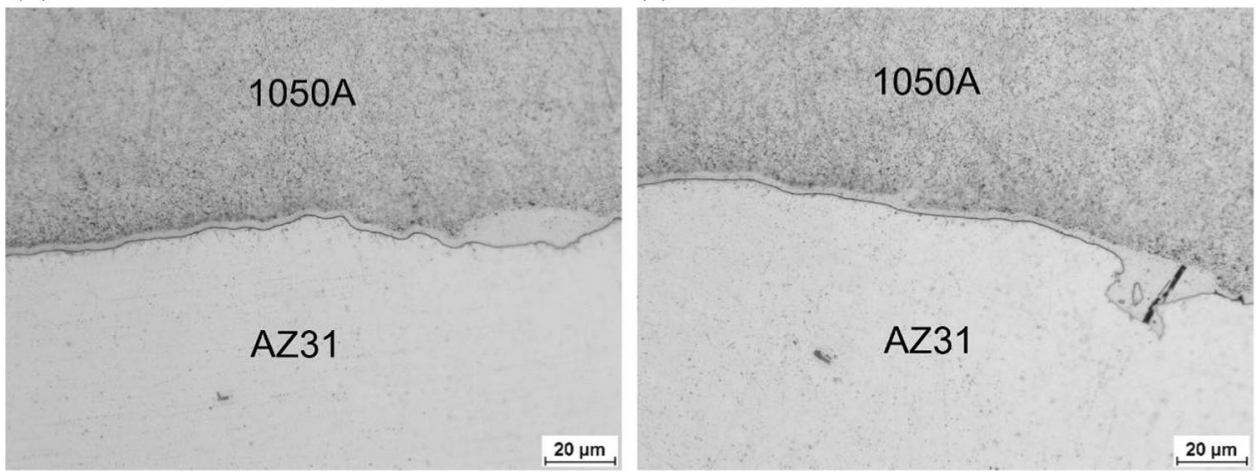

(a)

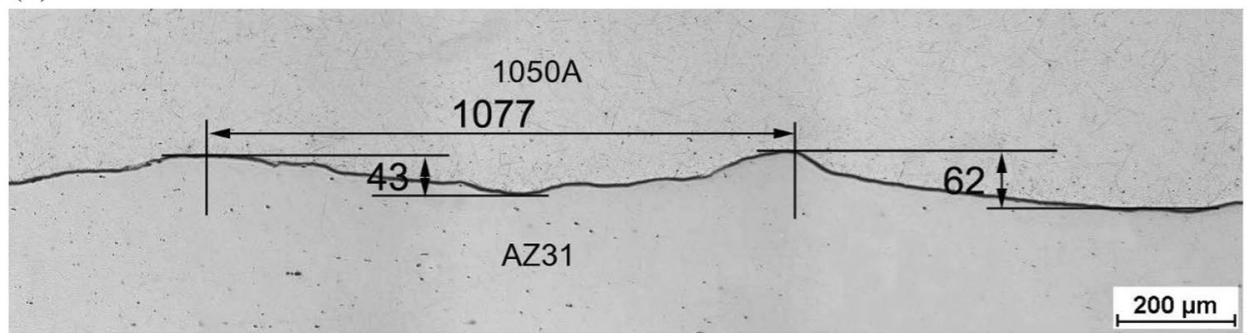

(b)

(c)
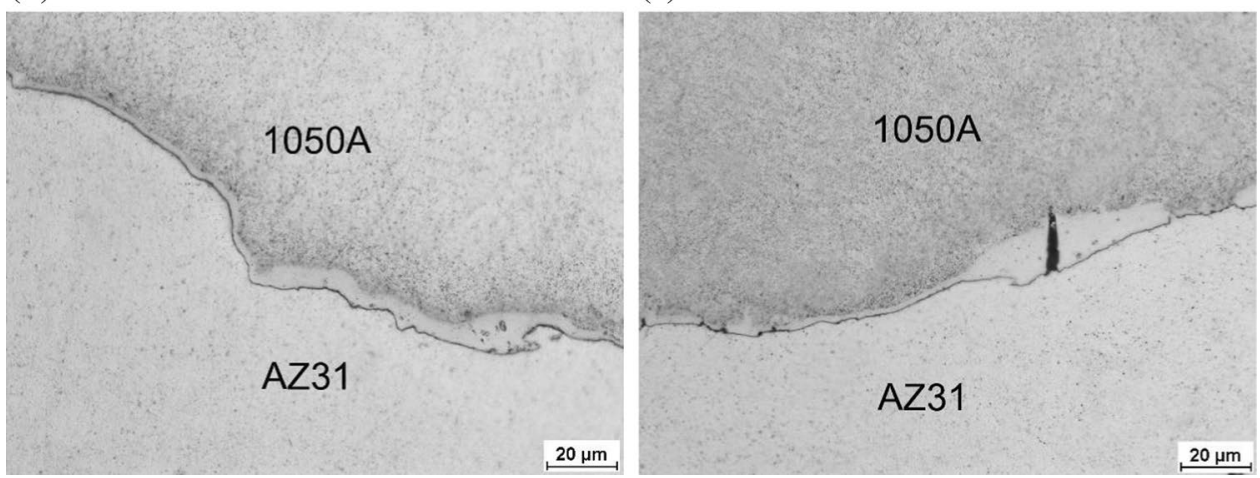

to the areas of $\mathrm{Mg}-\mathrm{Al}$ phases of irregular shape, that have been created during explosive welding between joined alloys, a very thin continuous interlayer (about $5 \mu \mathrm{m}$ ) was detected. No cracks were seen in this thin interlayer, singular cracks were only locally observed in thicker irregularshaped areas of the $\mathrm{Mg}-\mathrm{Al}$ intermetallic phases (Fig. 8c).
The microstructure of the interface of the 1050A/AZ31 bar at the longitudinal section after the rolling process at $300{ }^{\circ} \mathrm{C}$ was significantly changed. The distance between vertices of wave increased and the wave was highly flattened (Fig. 9a). In LM images at higher magnification (Fig. 9b, c), next to the $\mathrm{Mg}-\mathrm{Al}$ phases areas of irregular shapes, that 
have been created during explosive welding between joined alloys, also thin continuous interlayer was observed. As in the case of the transverse section, the singular cracks were locally observed in thicker irregular-shaped areas of the $\mathrm{Mg}-\mathrm{Al}$ intermetallic phases (Fig. 9c).

Figure 10 demonstrates the SEM image of the 1050A/ AZ31 interface of the explosive welded bar after rolling at $300{ }^{\circ} \mathrm{C}$. Here, the EDS line scan results show the concentration profiles of the $\mathrm{Mg}$ and $\mathrm{Al}$. A thin continuous interlayer rich in $\mathrm{Al}$ and $\mathrm{Mg}$ is clearly visible between the joined

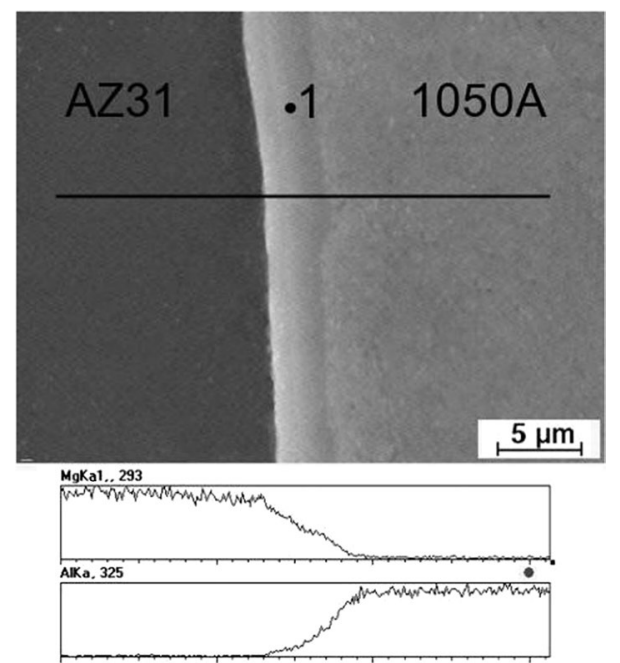

Fig. 10 SEM microstructure of the interface in 1050A/AZ31 bimetallic bar after rolling at $300{ }^{\circ} \mathrm{C}$ with a distribution of elements $(\mathrm{Mg}, \mathrm{Al})$ along the marked line alloys. The result of the quantitative EDS analysis in this layer (point 1 in Fig. 10: 40.54 at.\% $\mathrm{Mg}$ and 59.46 at.\% Al) indicates the presence of an $\mathrm{Al}_{3} \mathrm{Mg}_{2}$ intermetallic phase.

Figures 11 and 12 show the microstructure of the interface at the transverse and longitudinal sections of the 1050A/ AZ31 explosive welded bar after rolling at $400{ }^{\circ} \mathrm{C}$. At the transverse section, it can be observed that after the rolling process, the cambers and cavings present at the bond interface have been also highly flattened (Fig. 11a). At higher magnification, LM images (Fig. 11b, c) reveal a continuous interlayer between the joined alloys. This is much thicker (about $20 \mu \mathrm{m}$ ) as compared to that observed at the bimetal bar interface after rolling at $300{ }^{\circ} \mathrm{C}$. Cracks are also visible in this layer.

The analysis of the microstructure of the interface of the 1050A/AZ31 bar at the longitudinal section after the rolling process at $400{ }^{\circ} \mathrm{C}$ also shows that distance between vertices of wave increased and the wave was flattened (Fig. 12a). At higher magnification LM images (Fig. 12b, c) there are many cracks in interlayer at the bond interface.

Figure 13 presents the SEM image of the 1050A/AZ31 interface of the explosive welded bar after rolling at $400{ }^{\circ} \mathrm{C}$ with EDS line scan results. In the interlayer, two sublayers could be distinguished; the thinner one close to AZ31 (point 1) and the thicker one close to $1050 \mathrm{~A}$ (point 2). The chemical composition of the layer adjacent to AZ31 (EDS result in point 1: 61.74 at. $\% \mathrm{Mg}$ and 38.26 at.\% $\mathrm{Al}$ ) is close to the $\mathrm{Mg}_{17} \mathrm{Al}_{12}$ intermetallic phase. The layer adjacent to $1050 \mathrm{~A}$ (EDS result in point 2: 38.4 at.\% $\mathrm{Mg}$ and 61.6 at.\% $\mathrm{Al}$ ) was identified as an $\mathrm{Al}_{3} \mathrm{Mg}_{2}$ intermetallic phase.
Fig. 11 Microstructure of the bonding zone of a 1050A/AZ31 bimetallic bar after rolling at $400{ }^{\circ} \mathrm{C}$ : a low magnification LM image, b, c high magnification LM images. Transverse section (a)

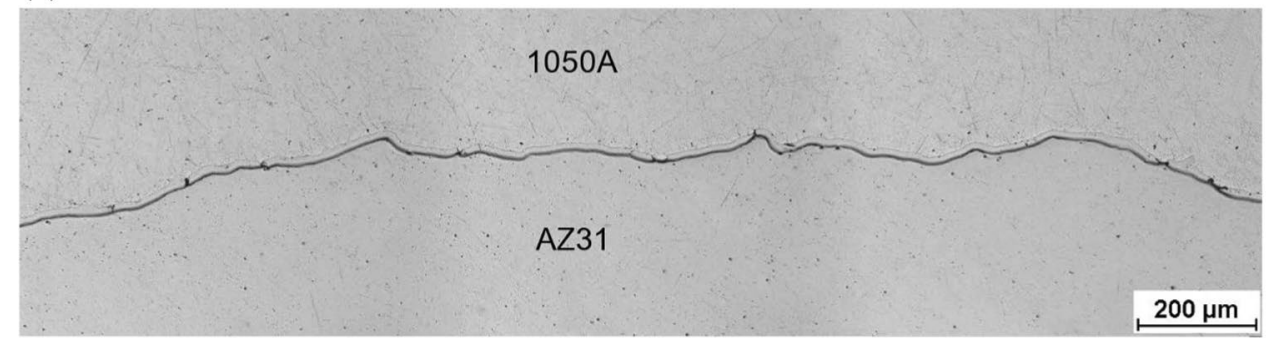

(b)

(c)

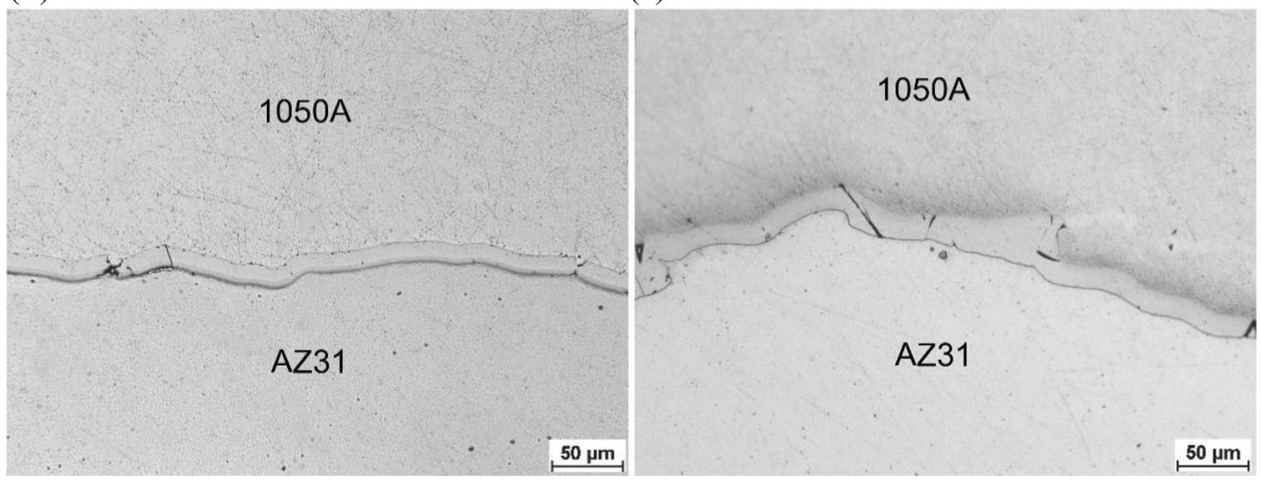


Fig. 12 Microstructure of the bonding zone of a 1050A/AZ31 bimetallic bar after rolling at $400{ }^{\circ} \mathrm{C}$ : a low magnification LM image, $\mathbf{b}, \mathbf{c}$ high magnification LM images. Longitudinal section

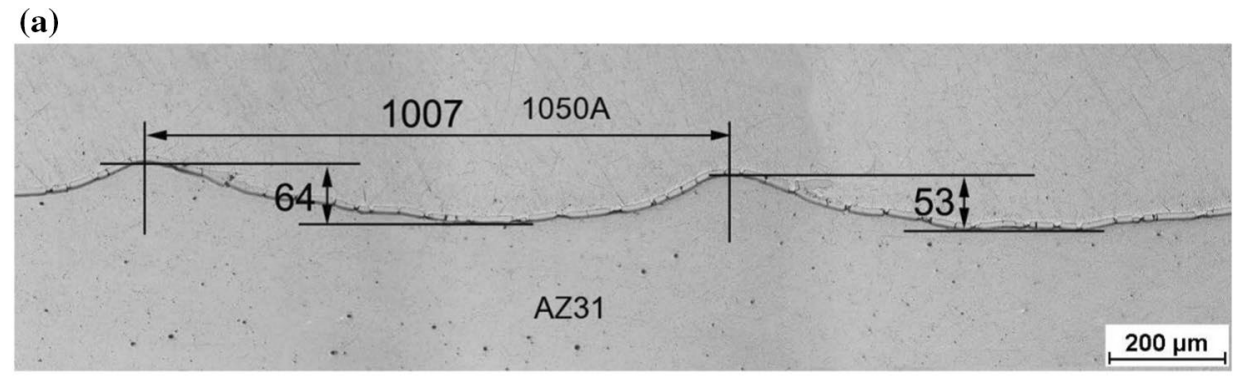

(b)

(c)

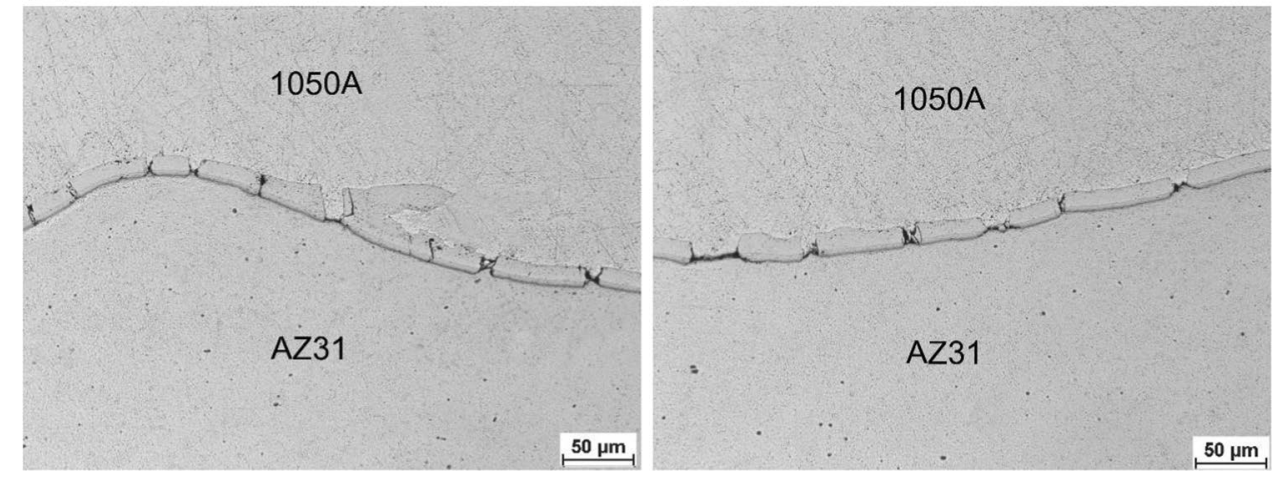

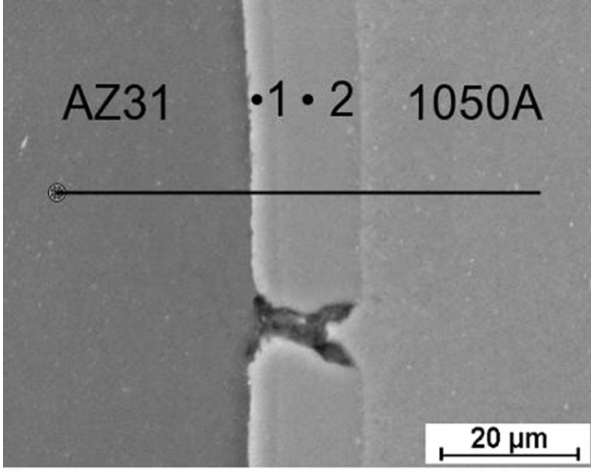

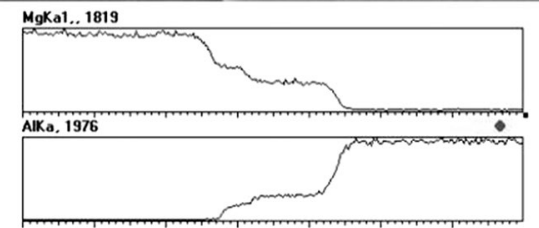

Fig. 13 SEM microstructure of the interface in 1050A/AZ31 bimetallic bar after rolling at $400{ }^{\circ} \mathrm{C}$ with a distribution of elements $(\mathrm{Mg}, \mathrm{Al})$ along the marked line

To sum up, the microstructure of the interface of the 1050A/AZ31 bar produced by explosive welding changed after the rolling process: with increasing rolling temperature, a thicker continuous zone composed of $\mathrm{Mg} / \mathrm{Al}$ intermetallic phases formed at the bond interface.

To determine the quality of the 1050/AZ31 bimetal samples joint following the explosive welding and rolling in passes at different temperatures, the shear strength tests were executed. The tests of the joint strength were done in testing dies, which shape was presented in the [28] work. Figure 14 presents the shape of bimetal samples after strength testing.

It comes from the data presented in Fig. 15, that properly selected explosive welding parameters, followed by a rolling process, ensured high quality of the joint. It has been found, that the joint quality was high enough so that its delamination did not occur in any case. The formation of the intermetallic layers at the 1050A/AZ31 interface in the rolling process did not reduce the strength of the joint. In every case being analyzed, only extrusion of cladding layer (1050A) through the testing die hole were observed. Therefore, the computational results of shear strength, presented in Fig. 15, characterize the shear strength of the cladding layer, and not the joint itself. The shear strength of samples following the explosive welding was $60 \mathrm{MPa}$. Whereas the shear strength of samples following rolling at $400{ }^{\circ} \mathrm{C}$ was reduced down to $45 \mathrm{MPa}$. Application of decreased rolling temperature $\left(300{ }^{\circ} \mathrm{C}\right)$ resulted in joint strength comparable to that obtained for feedstock after explosive welding.

To explain the influence of rolling temperature on the strength of joints analyzed above, a series of microhardness measurements were performed. Figure 16 shows the indentations left by the Vickers indenter near the interface of the 1050A/AZ31 bimetallic samples.

The values of the microhardness measurements were provided next to the indentations in these figures. These results show remarkable differences in the microhardness of the joined alloys directly after explosive welding and after rolling. The highest hardness of both joined alloys was reported in the 
Fig. 14 A shape of 1050A/ AZ31 bimetallic sample after the shearing test of the joining area: a sample after explosive welding (feedstock for the rolling process), $\mathbf{b}$ sample after rolling at $300{ }^{\circ} \mathrm{C}$, c sample after rolling at $400{ }^{\circ} \mathrm{C}[28]$
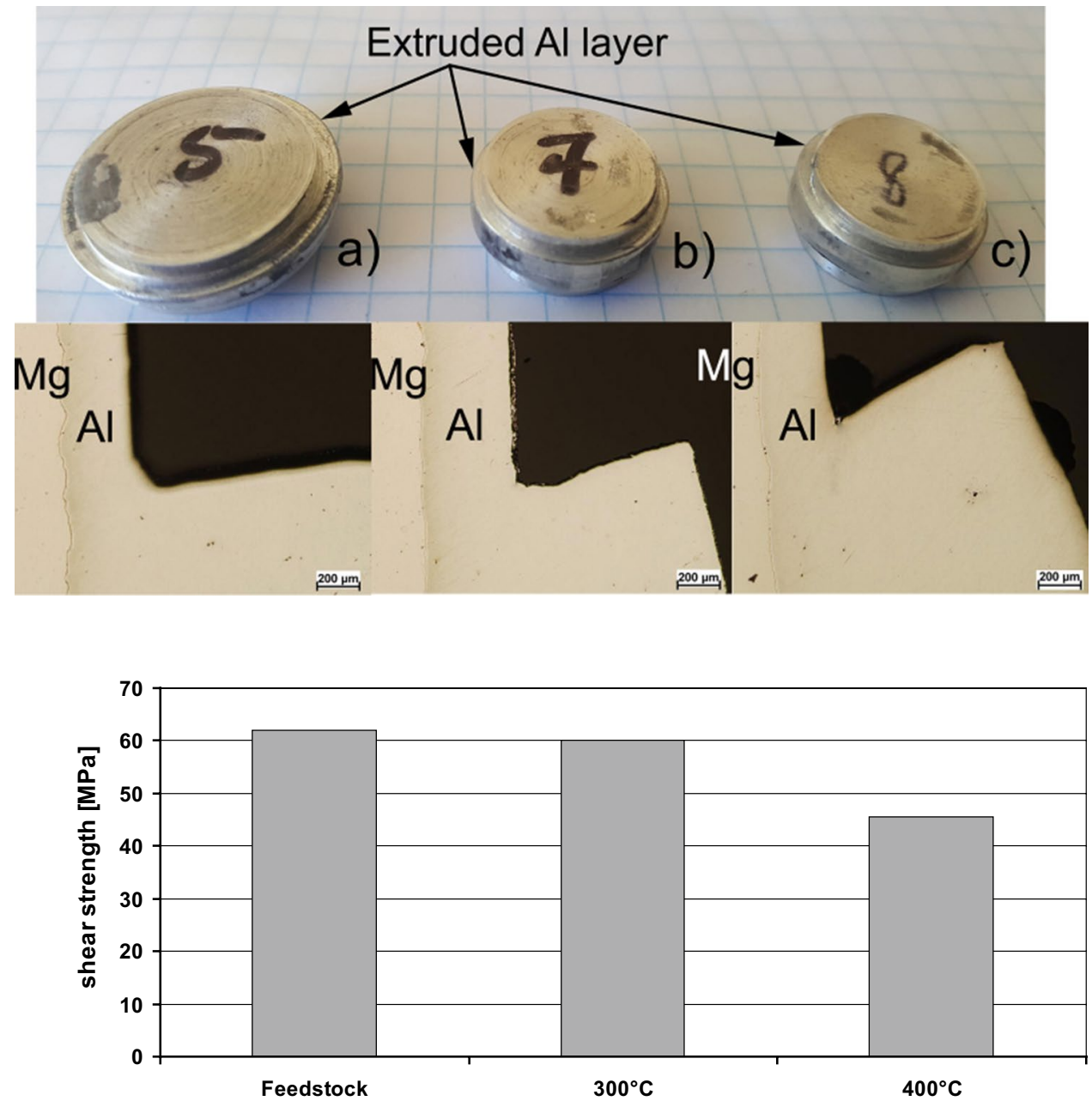

(a)

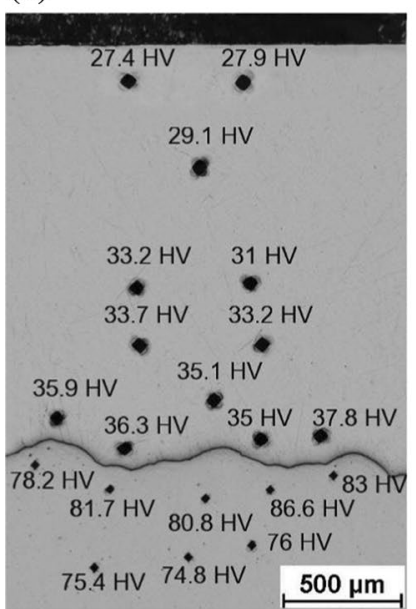

(b)

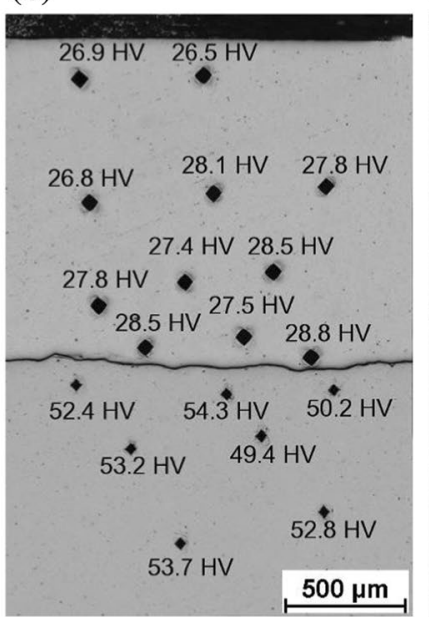

(c)

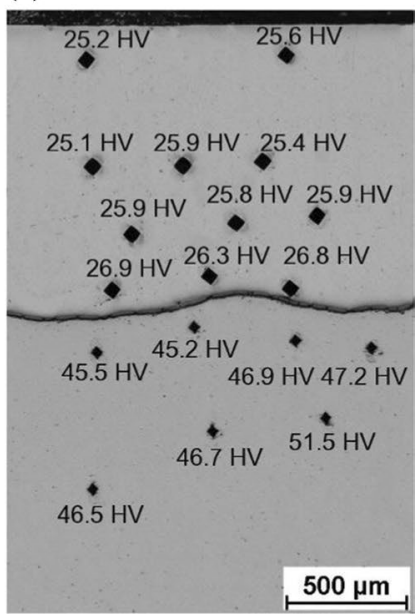

bimetallic bar directly after explosive welding. From Fig. 16a, it is clearly evident that the highest microhardness values, i.e. 35-37.8 HV for 1050A aluminium and 78.2-83 HV for AZ31 alloy were obtained near the bonding interface. In this case, the hardness of the AZ31 core was 62.1-64.1 HV. The high value of microhardness close to the bond interface indicates that huge plastic deformation in both alloys occurred in this area. Similar results have been reported by other researches [13, 21]. 
Lower values of microhardness were observed in the bimetal bar after rolling at $300{ }^{\circ} \mathrm{C}$ (Fig. 16b). The microhardness of the $1050 \mathrm{~A}$ close to the surface was $26.5-26.9 \mathrm{HV}$ and slightly higher values were reported close to the interface (27.5-28.5 $\mathrm{HV})$. The microhardness of the AZ31 near the interface was $50.2-54.3 \mathrm{HV}$. Higher values $(55.1-55.2 \mathrm{HV})$ were obtained in the AZ31 core. It was also found that the lowest microhardness values of the $1050 \mathrm{~A} / \mathrm{AZ} 31$ bar were after rolling at $400{ }^{\circ} \mathrm{C}$ (Fig. 16c). The microhardness values of 1050A next to the interface were slightly higher $(26.3-26.9 \mathrm{HV})$ than those close to the surface (25.2-25.6 HV). The microhardness measurements conducted for the AZ31 shows higher microhardness in the core (47.4-50.3 HV) than close to the interface (45.2-47.2 $\mathrm{HV})$. The above-mentioned results indicate that there is a correlation between the result of microhardness measurement and results of shear strength measurement of the 1050A/ AZ31 bars. In the bars after explosive welding, both materials (1050A aluminium and AZ31 magnesium alloy) had the highest microhardness values in areas near the bonding interface, so in this case, the highest shear strength of the joint. The explosive welded bars after rolling at $400{ }^{\circ} \mathrm{C}$ were characterized by the lowest microhardness of both alloys near bonding interface, thus they exhibited the lowest shear strength.

Computer simulations, performed by means of the Forge $2011^{\circledR}$ computer software, complemented the experimental research concerning the influence of rolling process temperature on the microstructure and quality of the joint. The application of the FE program requires the definition of boundary conditions which are decisive to the correctness of numerical computation. The properties of the 1050A and AZ31 alloy examined, friction conditions, and the kinetic and thermal parameters describing the hot rolling process. The FE analysis was performed for the laboratory conditions: the roll diameter $-150 \mathrm{~mm}$, coefficient of heat exchange between the material and the tool $\alpha-3000\left[\mathrm{~W} /\left(\mathrm{K} \mathrm{m}^{2}\right)\right]$, coefficient of heat exchange between the material and the air $\alpha_{\text {air }}-10$ $\left[\mathrm{W} /\left(\mathrm{K} \mathrm{m}^{2}\right)\right]$, stock temperature- 300 and $400{ }^{\circ} \mathrm{C}$, tool temperature $-60{ }^{\circ} \mathrm{C}$, ambient temperature $-20^{\circ} \mathrm{C}$, the rolling speed $-0.2 \mathrm{~m} / \mathrm{s}$. For numerical computations, the Coulomb and the Tresca mixed friction model was adopted; the value of the friction coefficient was assumed to be 0.08 , while that of the friction factor, 0.15 [35]. The flow stress, as dependent on the temperature and strain parameters for $1050 \mathrm{~A}$ and the AZ31 alloy was determined based on hot compression tests for the plane state of strain in the Gleeble3800 plastometer. The tests were planned so that the flow stress function and its coefficients could be developed for the conditions of the deformation process during a laboratory rolling process. For the description of the properties of the investigated materials, the Hensel-Spittel function [36] was employed:

$\sigma_{f}=A_{1} \exp ^{m_{1} T} \varepsilon^{m_{2}} \exp ^{\varepsilon m_{4}} \dot{\varepsilon}^{m_{3}}(1+\varepsilon)^{\frac{m_{5}}{\varepsilon}} \exp ^{\varepsilon m_{6}} \dot{\varepsilon}^{m_{7} T} T^{m_{8}}$

where: $\sigma_{f}$ is the flow stress (MPa), $T$ is the temperature $\left({ }^{\circ} \mathrm{C}\right.$ ), $\varepsilon$ is the true strain, $\dot{\varepsilon}$ is the strain rate $\left(\mathrm{s}^{-1}\right), A_{1}, \mathrm{~m}_{1}-\mathrm{m}_{8}$ is the coefficients.

Based on the performed approximation of the results of plastometric testing of 1050A and AZ31 with Eq. (1), the values of the flow stress function coefficients were obtained (Table 2).

The initial parameters, required for the computer simulations, were taken from earlier works of the authors. The junction between the core and the cladding layer was defined as closely fitting. The nodes of both meshes were shared. To increase the speed and accuracy of computations, $1 / 4$ of the feedstock cross-section and the symmetric half of one of the rolls were used in the simulations $[29,30]$. The computer simulations were constrained in the work to the first pass only. According to Fig. 3, the pass is of the circle-horizontal oval type. Figure 17 illustrates the geometrical model used for numerical computations. Because explosive joining usually results in wavy shape between individual components, the real shape of the joint was input into a numerical model, using to this end the data shown in Fig. 5a. The fragment of the joint shown in Fig. 5a was multiplicated up to $9 \mathrm{~mm}$ length. By means of rotation about the axis of the bar, the wavy shape of the joint was obtained on the whole periphery of 1050A/AZ31 feedstock.

Because the elongation factors applied in the analyzed pass for bars being rolled both at 300 and at $400{ }^{\circ} \mathrm{C}$

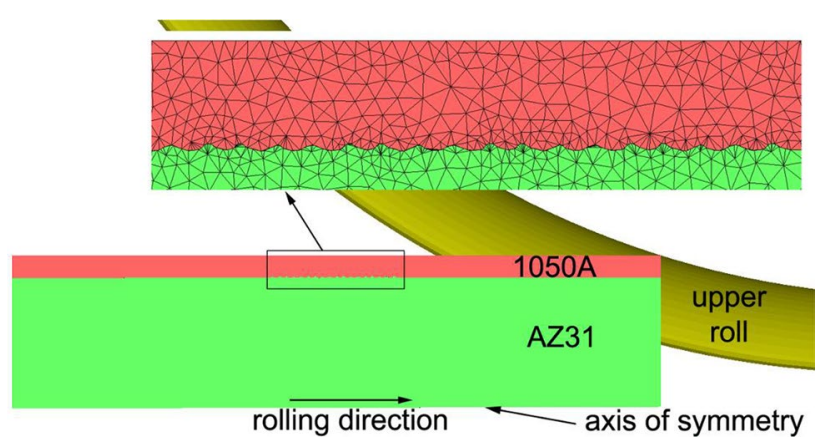

Fig. 17 The geometrical model used for numerical computations of 1050A/AZ31 bars rolling process
Table 2 Coefficients of the flow stress function (1)

\begin{tabular}{llllllllll}
\hline Material & $A_{1}$ & $m_{1}$ & $m_{2}$ & \multicolumn{1}{c}{$m_{3}$} & \multicolumn{1}{l}{$m_{4}$} & \multicolumn{1}{l}{$m_{5}$} & \multicolumn{1}{l}{$m_{6}$} & \multicolumn{1}{c}{$m_{7}$} & \multicolumn{1}{l}{$m_{8}$} \\
\hline 1050A & 0.08743 & -0.0099 & 0.11325 & -0.08845 & -0.00058 & -0.00153 & 0.196267 & 0.00048 & 1.71527 \\
AZ31 & 0.68478 & -0.0072 & 0.34242 & 0.02864 & -0.08199 & -0.00023 & -0.00439 & 0.00022 & 1.41094 \\
\hline
\end{tabular}


temperature were comparable, which resulted in comparable elongation of the waves on the border of the joint, analysis of rolling temperature influence on the thickness of cladding layer and height of waves after explosive welding and after rolling was performed in the work. Figure 19 presents the computed values of analyzed parameters for averaged values from Fig. 18.

It comes from the data shown in Figs. 18b, c and 19a, that in case where higher temperature is applied for rolling, higher reduction of cladding layer thickness occurs. This results from the fact, that higher differences in flow stress of individual bimetal components occur with the metal forming temperature increase [25]. This results in higher degree of cladding layer "flowing-off" the magnesium core. It can be seen in Fig. 18b, c, that thickness of cladding layer after 4 passes in the sample rolled at $300{ }^{\circ} \mathrm{C}$ was $1.35 \mathrm{~mm}$, while $1.27 \mathrm{~mm}$ in the sample rolled at $400{ }^{\circ} \mathrm{C}$. The measured thicknesses of cladding layer confirmed in a qualitative manner the results of numerical computations. A different situation was obtained for reduction of wave heights on the joint of components following rolling. Reduction of rolling temperature results in this case in the higher reduction of wave heights on the joint of components, as compared to a variant of rolling at $400{ }^{\circ} \mathrm{C}$.

To explain the cause of different character of wave heights reduction as compared to a reduction of cladding layer thickness, an analysis of effective strain distribution for the area of the joint was performed in the work (Fig. 20).

As mentioned above and in the work quoted [25, 30], deforming the 1050A/AZ31 bimetal products at temperature reduced down to $300{ }^{\circ} \mathrm{C}$, results in decreasing differences in flow stress values of individual components. This results in their more uniform deforming. Also in this case reduction of rolling temperature resulted in lower differences in obtained values of individual 1050Al/AZ31 components deformation. More uniform distribution of strain resulted in less intensive flowing the cladding layer of the magnesium alloy core and more intensive reduction of wave heights. This causes a local
Fig. 18 The height of cladding layer and wave height change within joint area following the first pass: a the feedstock after explosive welding; $\mathbf{b}$ bimetal bar after rolling at $300{ }^{\circ} \mathrm{C}$; c bimetal bar after rolling at $400{ }^{\circ} \mathrm{C}$, where: $T D$ thickness direction, $D D$ detonation direction, $R D$ rolling direction (all dimensions in $\mu \mathrm{m}$ ) (a)

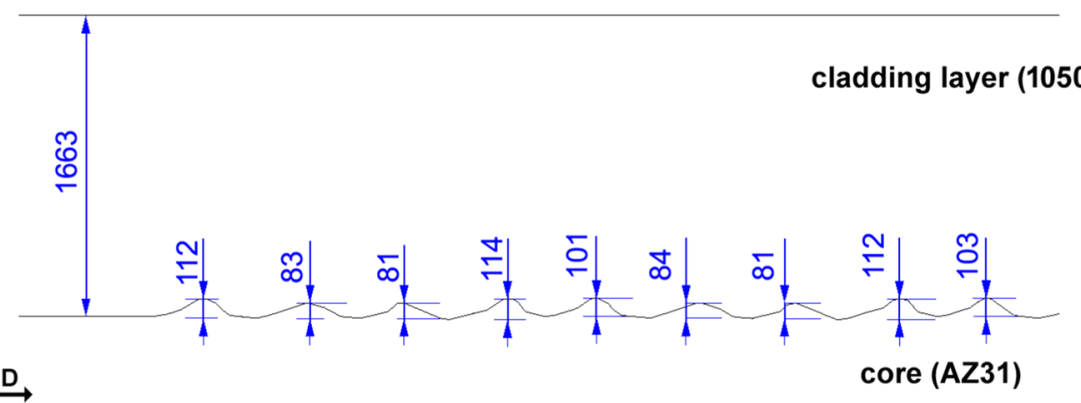

(b)

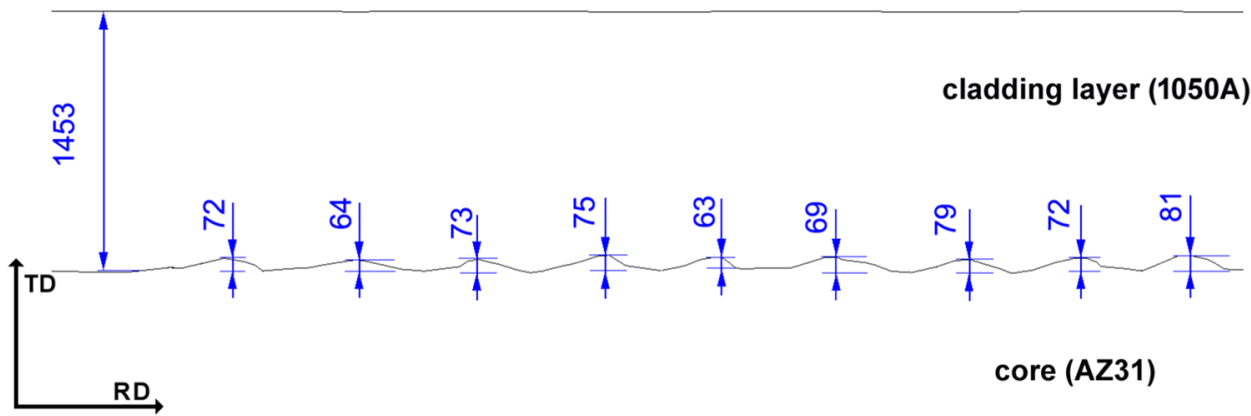

(c)

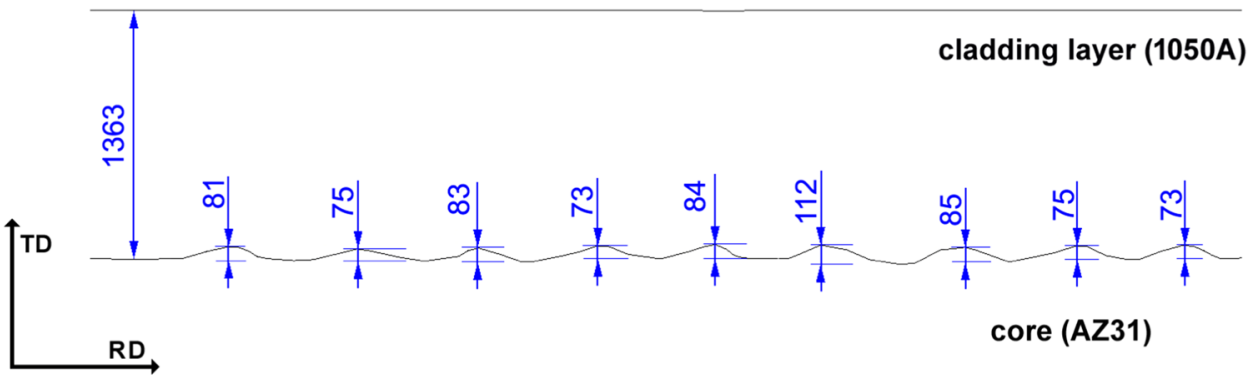



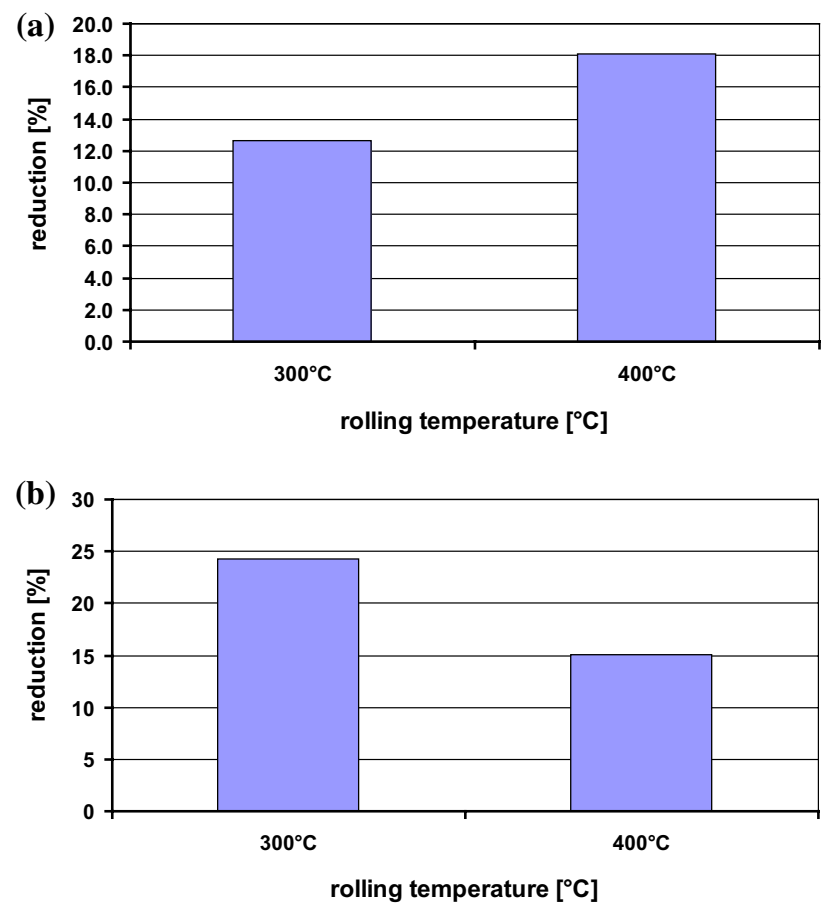

Fig. 19 Reduction of cladding layer height (a) and height of waves on the joint of components (b) after rolling the 1050A/AZ31 bars in the first pass

(a)

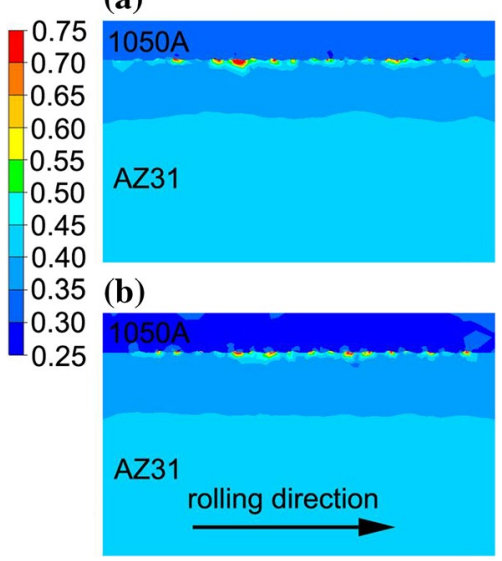

Fig. 20 Distribution of the effective strain on the joining area: a rolling at $300{ }^{\circ} \mathrm{C}$, b rolling at $400{ }^{\circ} \mathrm{C}$

increase in effective strain value, which is shown in Fig. 20a. From the other hand, rolling the bimetal bars at $400{ }^{\circ} \mathrm{C}$ results in higher differences in flow stress of individual components (Fig. 20b), which leads to higher flowing the cladding layer off, but not to reduction of wave heights. In this case, higher differences in obtained values of effective strain were noted, and local increase of effective strain within areas of waves is lower. The data presented in Figs. 9a and 12a constitute confirmation of obtained theoretical computations results, from which it comes that total elongation of wave frequency lengths is similar and corresponds to the total one. The wave amplitude obtained in the numerical modeling (Fig. 18) compared to the wave amplitude obtained in samples after the rolling process shows the same trend. However, during rolling at $400{ }^{\circ} \mathrm{C}$, the amplitude of the wave is higher due to the occurrence of lower values of the flow stress and greater reduction of the cladding layer (see Figs. 19 and 20) as well as the "flowing-off" the cladding layer. When the rolling process was conducted at a temperature of $300{ }^{\circ} \mathrm{C}$, the thickness distribution of the cladding layer and the wave amplitude was inverse than that for a higher temperature. In theoretical studies, the higher amplitude of the wave height was obtained compared to the experimental results. It was closely related to the temperature distribution in the subsurface layers of the samples. In numerical modeling, the initial temperature distribution was uniform. While in experimental rolling the subsurface layers of the heated samples cool down during transport from the furnace to the mill. For this reason, the wave amplitude obtained in the numerical modeling is greater than the wave amplitude determined in experimental studies.

\section{Conclusions}

The 1050A/AZ31 bimetallic bar was fabricated by the explosive welding process. The influence of the temperature of the rolling process on the microstructure and properties of the joining area in the 1050A/AZ31 bars was experimentally and theoretically studied and the following conclusions were drawn:

- after the explosive welding process, the interface of the 1050A/AZ31 bars had wavy morphology. Locally, at the interface, small irregular shaped areas of $\mathrm{Mg}-\mathrm{Al}$ phases are observed;

- during the hot rolling process, a continuous interlayer composed of $\mathrm{Mg}-\mathrm{Al}$ intermetallic phases formed at the 1050A/AZ31 interface. The thickness of interlayer increased with the increase of rolling temperature. After the rolling process at $300{ }^{\circ} \mathrm{C}$, the interlayer in the 1050A/ AZ31 bars was very thin and continuous. Applying a higher temperature $\left(400^{\circ} \mathrm{C}\right)$ led to the formation of a much thicker interlayer which underwent high fragmentation during the rolling process;

- irrespective of rolling temperature applied, high strength of the joint was obtained, higher than the strength of the cladding layer;

- the microhardness measurements indicate that 1050A/ AZ31 bars directly after explosive welding are characterized by the highest microhardness in both components of the bimetallic bars near the bonding interface. After 
the rolling process, the microhardness value in that area decreased but the higher decrease was evident for bars rolled at $400{ }^{\circ} \mathrm{C}$; decreasing temperature of rolling results in more uniform deformation of individual bimetal components and higher reduction of wave heights at the border of joint.

Funding The study was financed in the years 2015-2018 from the National Scientific Centre's resources granted under Decision no. DEC-2013/11/B/ST8/04352/1

\section{Compliance with ethical standards}

Conflict of interest The authors declare that they have no conflict of interest.

Ethical statement The work has been prepared according to common ethical standards.

Open Access This article is licensed under a Creative Commons Attribution 4.0 International License, which permits use, sharing, adaptation, distribution and reproduction in any medium or format, as long as you give appropriate credit to the original author(s) and the source, provide a link to the Creative Commons licence, and indicate if changes were made. The images or other third party material in this article are included in the article's Creative Commons licence, unless indicated otherwise in a credit line to the material. If material is not included in the article's Creative Commons licence and your intended use is not permitted by statutory regulation or exceeds the permitted use, you will need to obtain permission directly from the copyright holder. To view a copy of this licence, visit http://creativecommons.org/licenses/by/4.0/.

\section{References}

1. Pan F, Yang M, Chen X. A review on casting magnesium alloys: modification of commercial alloys and development of new alloys. J Mater Sci Technol. 2016;32(12):1211-21.

2. Dursun T, Soutis C. Recent developments in advanced aircraft aluminium alloys. Mater Des. 2014;56:862-71.

3. Mahendran G, Balasubramanian V, Senthilvelan T. Developing diffusion bonding windows for joining AZ31B magnesiumAA2024 aluminium alloys. Mater Des. 2009;30:1240-4.

4. Zhu B, Liang W, Li X. Interfacial microstructure, bonding strength and fracture of magnesium-aluminium laminated composite plates fabricated by direct hot pressing. Mater Sci Eng A. 2011;528:6584-8.

5. Zhang XP, Yang TH, Castagne S, Wang JT. Microstructure; bonding strength and thickness ratio of $\mathrm{Al} / \mathrm{Mg} / \mathrm{Al}$ alloy laminated composites prepared by hot rolling. Mater Sci Eng A. 2011;528:1954-60.

6. Luo Ch, Liang W, Chen Z, Zhang J, Chi Ch, Yang F. Effect of high temperature annealing and subsequent hot rolling on microstructural evolution at the bond-interface of $\mathrm{Al} / \mathrm{Mg} / \mathrm{Al}$ alloy laminated composite. Mater Charact. 2013;84:34-40.
7. Feuerhack B, Binotsch C, Wolff A, Awiszus B, Kittner K. A numerical criterion for quality prediction of bimetal strands. J Mater Process Technol. 2014;214:183-9.

8. Golovko O, Bieliaiev SM, Nürnberger F, Danchenko VM. Extrusion of the bimetallic aluminium-magnesium rods and tubes. Forsch Ingenieurwes. 2015;79:17-27.

9. Sato YS, Park SHC, Michiuchi M, Kokawa H. Constitutional liquation during dissimilar friction stir welding of $\mathrm{Al}$ and $\mathrm{Mg}$ alloys. Script Mater. 2004;50:1233-6.

10. Liu L, Ren D, Liu F. A review of dissimilar welding techniques for magnesium alloys to aluminium alloys. Materials. 2014;7:3735-57.

11. Emami SM, Divandari M, Arabi H, Hajjari E. Effect of melt-tosolid insert volume ratio on $\mathrm{Mg} / \mathrm{Al}$ dissimilar metals bonding. $\mathrm{J}$ Mater Eng Perform. 2013;22(1):123-30.

12. Mola R, Bucki T. The microstructure and properties of the bimetallic AZ91/A1Si17 joint produced by compound casting. Arch Foundry Eng. 2018;18(1):71-6.

13. Ghaderi SH, Mori A, Hokamoto K. Analysis of explosively welded aluminium-AZ31 magnesium alloy joints. Mater Trans. 2008;49(5):1142-7.

14. Fronczek DM, Chulist R, Litynska-Dobrzynska L, Kac S, Schell N, Kania Z, Szulc Z, Wojewoda-Budka J. Microstructure and kinetics of intermetallic phase growth of three-layered A1050/ AZ31/A1050 clads prepared by explosive welding combined with subsequent annealing. Mater Des. 2017;130:120-30.

15. Okamoto $\mathrm{H}$. Al-Mg (aluminum-magnesium). J Phase Equilib. 1998:19:598.

16. Mola R, Mroz S, Szota P. Effects of the process parameters on the formability of the intermetallic zone in two-layer $\mathrm{Mg} / \mathrm{Al}$ materials. Arch Civ Mech Eng. 2018;18:1401-9.

17. Xiao L, Wang N. Growth behavior of intermetallic compounds during reactive diffusion between aluminum alloy 1060 and magnesium at 573-673 K. J Nucl Mater. 2015;456:389-97.

18. Mola R, Bucki T, Gwoździk M. The effect of a zinc interlayer on the microstructure and mechanical properties of a magnesium alloy (AZ31)-aluminum alloy (6060) joint produced by liquidsolid compound casting. JOM. 2019;71(6):2078-86.

19. Liu N, Chen L, Fu Y, Zhang Y, Tan T, Yin F, Liang Ch. Interfacial characteristic of multi-pass caliber-rolled $\mathrm{Mg} / \mathrm{Al}$ compound casting. J Mater Process Technol. 2019;267:196-204.

20. Findik F. Recent developments in explosive welding. Mater Des. 2011;32:1081-93.

21. Zhang LJ, Pei Q, Zhang JX, Bi ZY, Li PC. Study on the microstructure and mechanical properties of explosive welded 2205/ X65 bimetal sheet. Mater Des. 2014;64:462-76.

22. Zhang N, Wang W, Cao X, Wu J. The effect of annealing on the interface microstructure and mechanical characteristic of AZ31B/ AA6061 composite plates fabricated by explosive welding. Mater Des. 2015;65:1100-9.

23. Mróz S, Szota P, Stefanik A, Mola R (2018) Properties of joint region in the $\mathrm{Mg} / \mathrm{Al}$ two-layer materials after explosive welding process. In: METAL 2018-27th international conference on metallurgy and materials, conference proceedings, Brno, Czech Republic, 23-25 May 2018, pp 1647-1653

24. Mroz S, Stradomski G, Dyja H, Galka A. Using the explosive cladding method for production of $\mathrm{Mg}-\mathrm{Al}$ bimetallic bars. Arch Civ Mech Eng. 2015;15:317-23.

25. Mróz S, Gontarz A, Drozdowski K, Bala H, Szota P. Forging of $\mathrm{Mg} / \mathrm{Al}$ bimetallic handle using explosive welded feedstock. Arch Civ Mech Eng. 2018;18:401-12.

26. Szota P, Mróz S, Gontarz A, Stefanik A. Theoretical and experimental analysis of $\mathrm{mg} / \mathrm{al}$ bimetallic handle forging process. Arch Metall Mater. 2019;64(4):1503-12.

27. Chen Z, Wang D, Cao X, Yang W, Wang W. Influence of multi-pass rolling and subsequent annealing on the interface 
microstructure and mechanical properties of the explosive welding $\mathrm{Mg} / \mathrm{Al}$ composite plates. Mater Sci Eng A. 2018;723:97-108.

28. Mróz S, Stefanik A, Szota P. Groove rolling process of Mg/Al bimetallic bars. Arch Metall Mater. 2019;64(3):1067-72.

29. Mróz S, Szota P, Bajor T, Stefanik A. Theoretical and experimental analysis of formability of explosive welded $\mathrm{Mg} / \mathrm{Al}$ bimetallic bars. Arch Metall Mater. 2017;62(2):501-7.

30. Mróz S, Szota P, Stefanik A. FE and physical modelling of plastic flow the two-layer $\mathrm{Mg} / \mathrm{Al}$ materials. Comput Methods Math Sci. 2017;17(3):148-55.

31. Mroz S, Szota P, Bajor T, Stefanik A. Formability of explosive welded Mg/Al bi-metallic bar. Key Eng Mater. 2016;716:114-20.

32. Paul H, Miszczyk MM, Chulist R, Prażmowski M, Morgiel J, Gałka A, Faryna M, Brisset F. Microstructure and phase constitution in the bonding zone of explosively welded tantalum and stainless steel sheets. Mater Des. 2018;153:177-89.

33. Paul H, Chulist R, Miszczyk M, Litynska-Dobrzynska L, Cios G, Gałka A, Petrzak P, Szlezynger M. Towards a better understanding of the phase transformations in explosively welded copper to titanium sheets. Mater Sci Eng A. 2020;784:139285.

34. Dyja H, Mróz S, Stradomski Z. Properties of joint in the bimetallic rods $\mathrm{Cu}-\mathrm{Al}$ and $\mathrm{Cu}-$ steel after explosive cladding and the process of rolling. Metallurgy. 2003;42(3):185-91.

35. Dziubinska A, Gontarz A, Zagórski I. Qualitative research on AZ31 magnesium alloy aircraft brackets with a triangular rib produced by a new forging method. Aircr Eng Aerosp Technol. 2018;90(3):482-8.

36. Hensel A, Spittel T. Kraft und Arbeitsbedarf Bildsomer Formgeburgs. Lipsk: Verfahren, VEB Deutscher Verlang für Grundstoffindustrie; 1979.

Publisher's Note Springer Nature remains neutral with regard to jurisdictional claims in published maps and institutional affiliations. 